Original Article

\title{
Impact of treated sewage on meiobenthic nematodes: a case study from the Tunisian Refining Industries Company
}

\author{
Impacto de esgoto tratado em nematoides meiobentônicos: um estudo de caso da \\ Tunisian Refining Industries Company
}

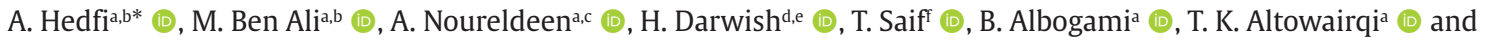 \\ F. Boufahjab ${ }^{\mathrm{B}}$ \\ a Department of Biology, College of Sciences, Taif University, P.O. Box 11099, Taif 21944, Saudi Arabia \\ b Laboratory of Biomonitoring of the Environment LR01 ES14, University of Carthage, Faculty of Sciences of Bizerte, Zarzouna 7021, Tunisia \\ c Department of Agricultural Zoology, Faculty of Agriculture, Mansoura University, Mansoura 35516, Egypt \\ d Department of Biotechnology, College of Sciences, Taif University, P.O. Box 11099, Taif 21944, Saudi Arabia \\ e Department of Medicinal and Aromatic Plants, Horticulture Institute, Agriculture Research Center, Giza 12619, Egypt \\ ${ }^{\mathrm{f}}$ National Institute of Oceanography and Fisheries, Cairo, Egypt
}

\begin{abstract}
The main objective of the current study was to assess the impact of the water taken from the 'Tunisian Refining Industries Company' on meiobenthic nematodes, before and after a series of treatments in decantation basins followed by its discharge in Bizerte bay, Tunisia. The comparison of environmental parameters of the two types of water was clearly indicative of an improvement in the quality of treated waters after a significant reduction in their loads in hydrocarbons. Overall, the water retained a good quality after being treated by 'Tunisian Refining Industries Company' before discharge in the sea. At the end of the experiment, differential responses were observed according to the richness of sediment in organic matter and hydrocarbons. Thus, it was apparent that the nematode assemblage exposed to the treated waters was closer to controls and associated to higher values of abundance, than that under untreated ones. It was also assumed that the species Microlaimus honestus De Man, 1922, Paramonohystera proteus Wieser, 1956 and Cyartonema germanicum Juario, 1972 are sensitive bioindicators of bad environmental statues and of hydrocarbon presence in the environment. On the other hand, Metoncholaimus pristiurus (Zur Strassen, 1894) Filipjev, 1918 would rather be classified as a positive bioindicative species of this type of pollutants.
\end{abstract}

Keywords: meiobenthic nematodes, microcosms, refinery, taxonomy, treated sewage.

\begin{abstract}
Resumo
O principal objetivo do presente estudo foi avaliar o impacto da água retirada da "Tunisian Refining Industries Company" sobre os nematoides meiobentônicos, antes e depois de uma série de tratamentos em bacias de decantação seguidos de seu descarte na baía de Bizerte, Tunísia. A comparação dos parâmetros ambientais dos dois tipos de água foi claramente indicativa de uma melhoria na qualidade das águas tratadas após uma redução significativa das suas cargas em hidrocarbonetos. No geral, a água reteve uma boa qualidade após ser tratada pela "Tunisian Refining Industries Company" antes da descarga no mar. Ao final do experimento, foram observadas respostas diferenciais de acordo com a riqueza de sedimentos em matéria orgânica e hidrocarbonetos. Assim, ficou claro que a assembleia de nematoides exposta às águas tratadas estava mais próxima dos controles e associada a maiores valores de abundância do que nas não tratadas. Também foi assumido que as espécies Microlaimus honestus De Man, 1922, Paramonohystera proteus Wieser, 1956 e Cyartonema germanicum Juario, 1972 são bioindicadores sensíveis de más estátuas ambientais e da presença de hidrocarbonetos no meio ambiente. Por outro lado, Metoncholaimus pristiurus (Zur Strassen, 1894) Filipjev, 1918 preferiria ser classificado como uma espécie bioindicativa positiva deste tipo de poluentes.
\end{abstract}

Palavras-chave: nematoides meiobentônicos, microcosmos, refinaria, taxonomia, esgoto tratado.

\section{Introduction}

Oil refining is the separation of different hydrocarbons based on their molecular weight. The process is complex one and entails a set of treatments and transformations in order to yield the maximum number of products of commercial value. As a consequence, the refining industry exerts an impact on local ecosystems (Kennish, 1992; Rohal et al., 2020) and represents an undoubtable source of pollution despite the implementation of mitigation practices such

*e-mail: o.zaied@tu.edu.sa

Received: December 1, 2020 - Accepted: January 5, 2021 
as the treatments of refinery wastewater. Following the refining process, the water undergoes a set of treatments aiming towards the elimination of the hydrocarbons before being discharged in the marine environment.

In Tunisia, the "Tunisian Refining Industries Company (TRIC)", established in 1961, is located near the Bay of Bizerte (latitude $37^{\circ} .2562176184 \mathrm{~N}$ and longitude $9^{\circ} .88961598291$ E). It operates as the only industrial area specialized in refining crude oil in Tunisia (Zrafi-Nouira et al., 2009). The continuous flow of hydrocarbons discharged with the washing and cooling water from TRIC, as well as the wastewater spread occurring during jettison, imply that hydrocarbon concentration of the waste water may occasionally exceed the acceptable standards (Beyrem and Aïssa, 2000). This could be the onset of ecological disturbance in areas where such activities take place. This company uses seawater for treating the oil effluents in the refining process and in the cleaning of petroleum tanks (Zrafi-Nouira et al., 2009, 2010). According to ZrafiNouira et al. (2009, 2010), the water to be treated undergoes progressively into five successive decantation tanks, in order to extract the maximum oil, with the seawater used in the procedure being discharged in the Bizerte bay.

Free-living marine nematodes represent an excellent group for experimental and ecotoxicological studies due to their small size ( 1 to $5 \mathrm{~mm}$ ), high abundance (up to 23 millions per $\mathrm{m}^{2}$ ) and short life cycles (Mahmoudi et al., 2005; Hedfi et al., 2008; Hedfi et al., 2018). The toxic effect of hydrocarbons on the marine meiofauna has already been shown in previous studies. Indeed, the toxicity of hydrocarbons is held responsible for a loss of abundance and nematological diversity, by the disappearance of the most sensitive species and survival of the most tolerant ones (Beyrem and Aïssa, 2000; Mahmoudi et al., 2003). Data of Mahmoudi et al. (2005) and Allouche et al. (2020) supported that petroleum products (diesel, chrysene, phenanthrene and fluoranthene) were harmful for Microlaimids, especially the species Microlaimus honestus. In contrast, the tolerance towards anthracene was supported by results of Allouche et al. (2020) in the case of Oncholaimids, namely Metoncholaimus pristiurus, Thoonchus inermis and Oncholaimellus calvadocicus. Furthermore, the negative effect of the environmental hydrocarbon contamination has been correlated with changes in nematode biomass (Mahmoudi et al., 2005).

In this study, the effects of TRIC waste waters, before and after treatments in decantation basins, were investigated in terms of their effects on free-living nematodes. Our results will contribute in assessing the environmental conditions using these organisms. Moreover, it will identify those nematode species that are the most suitable and could act as indicators for future surveillance and monitoring actions in terms of impacts of refining waste water.

\section{Material and Methods}

\subsection{Characteristics of the untreated waters and those treated by TRIC}

The quality of the untreated waters and those treated by TRIC was assessed by the determination of several chemical and physical parameters ( $\mathrm{pH}$, electronic conductivity, decantable and suspended materials, Biochemical Oxygen Demand (BOD), Chemical Oxygen Demand (COD), according to the methods described by Rodier (1996) and Aminot and Kérouel (2004). The concentration of hydrocarbons was determined by chromatography in gas phase after liquid/liquid extraction with hexane containing two markers (C10 n-decane and C40 tetracontane). In between, the extracts were concentrated using rotary evaporation (Saliot, 1981).

\subsection{Sediment sampling}

The study area is located on the west coast of the Bizerte bay, Tunisia ( $\left.37^{\circ} 16^{\prime} 5.44^{\prime \prime} \mathrm{N}, 9^{\circ} 53^{\prime} 4.88^{\prime \prime} \mathrm{E}\right)$, about $500 \mathrm{~m}$ from the wastewater rejection areas of the TRIC. The sediment was collected on April $8^{\text {th }}, 2015$ (7 A.M) off the subtidal upper fringe, at a depth of $10 \mathrm{~cm}$ (Hedfi et al., 2021 ), using $10 \mathrm{~cm}^{2}$ hand-cores (3.6 cm inner diameter) (Coull and Chandler, 1992) and subsequently transferred into a bucket. On the sampling day, two parameters were considered at the sediment-water interface, i.e $\mathrm{pH}$ and conductivity, and measured with a pH meter (WTW, model pH 330 / SET-1) and a temperature/conductivity meter (WTW LF 196, Weilheim, Germany), respectively.

\subsection{Granulometry and sedimentary hydrocarbons}

Sediment samples were first dried at $45^{\circ} \mathrm{C}$ until reaching a constant weight following the methodology described by Fabiano and Danovaro (1994). Thereafter, percentages of silt/clay $(<63 \mu \mathrm{m})$ and coarse particles $(\geq 63 \mu \mathrm{m})$ were estimated through passing the sediment over a $63 \mu \mathrm{m}$ sieve (Buchanan, 1971). The mean grain size was deduced from logarithmic cumulative curves established for the coarse fraction (Buchanan, 1971). Finally, sub-samples of sediment were heated $\left(450{ }^{\circ} \mathrm{C}, 6\right.$ hours $)$ to determine the Total Organic Matter (TOM; Fabiano and Danovaro, 1994).

Hydrocarbon was extracted from the sediments with carbon tetrachloride, which is an organic solvent (Danovaro et al., 1995). The concentrations of hydrocarbons were then determined by infrared spectrophotometry using a PERKIN-ELMER FT-IR spectrometer, spectrum 1000 (Danovaro et al., 1995).

\subsection{Experimental set-up}

Sediment was collected the same day from the study area, and then subdivided in different microcosms, as described below. Three different treatments were tested in the experimental set up and each of them consisted of three replicates, and thus a total of nine microcosms were set up. Each microcosm, i.e. a glass bottle of one liter (Hedfi et al. 2013; Wakkaf et al. 2020), was filled with $500 \mathrm{~g}$ of the collected sediments. Three bottles were filled with $350 \mathrm{~mL}$ of the natural sea water and considered as the control treatment $(\subset$, while the remaining bottles were filled with $350 \mathrm{~mL}$ of water collected before (untreated water: UW) and after its treatment (treated water: TW) by the TRIC.

Each microcosm was an isolated enclosure and was continuously ventilated with an aquarium pump by means of a plastic pipe inserted through a hole into its lid 
(Austen et al., 1994; Mahmoudi et al., 2005; Beyrem et al., 2007; Boufahja et al., 2011). The microcosms were acclimatized for three days prior to the beginning of the study. The total duration of the experiment was 30 days (Hedfi et al., 2007; Essid et al., 2020; Allouche et al., 2020).

\subsection{Sample processing}

Meiofauna, here defined as the metazoans with a body size between $1 \mathrm{~mm}$ and $40 \mu \mathrm{m}$ (Hedfi et al., 2007), were extracted from the sediments after sieving and the subsequent resuspension-settling methodology (Wieser, 1960). The organisms were stained with Rose-Bengal $\left(0.2 \mathrm{~g} \mathrm{~L}^{-1}\right)$ (Guo et al., 2001) and fixed in $4 \%$ formalin (Allouche et al., 2020; Nasri et al., 2020).

After extraction, maximum of 100 nematodes (Kotta and Boucher, 2001) from each microcosm were picked under a stereo dissecting microscope (Model WildHeerbrugg M5A). The collected nematodes were mounted on slides as described by Seinhorst (1959) for biomass determination and microscopic identification by a Nikon DS-Fi2 camera coupled with a Nikon microscope (Image Software NIS Elements Analysis Version 4.0 Nikon 4.00.07-build 787-64 bit), using the pictorial keys of Platt and Warwick (1983, 1988), and Warwick et al. (1998), and descriptions downloaded from the Nemys database developed by the nematologists of Ghent University (Belgium) (Bezerra et al., 2020). The body volume of the nematodes was estimated from measurements of body length and width using the Andrassy formula $\mathrm{V}=\mathrm{L} \times \mathrm{W}^{2} / 16 \times 10^{5}$, (V: volume in nanoliters; L: length in micrometer, $\mathrm{W}$ : maximum width in micrometer). The wet weight of nematodes (in $\mu$ g) was estimated after multiplying their volume by the body gravity (=1.13 $\mu \mathrm{g} \cdot \mathrm{nl}^{-1}$ according to Wieser, 1960). Finally, the dry weight was calculated based on the ratio of 0.25 relating dry and wet weights (Vanaverbeke et al., 1997).

\subsection{Statistical analyses}

All data were tested for normality (KolmogorovSmirnov test) and equality of variance (Bartlett test). Data were $\log _{10}(\mathrm{x})$ transformed to fulfill the requirements of parametric analyses (Clarke, 1993; Clarke and Gorley, 2001). Univariate and multivariate analyses were performed using the PRIMER V.5 software package (Clarke, 1993; Clarke and Gorley, 2001) with the exception of the one-way ANOVA and Tukey's HSD test that were run in STATISTICA v8.0. For each microcosm the number of species (S), the diversity $\left(\mathrm{H}^{\prime} \log _{\mathrm{e}}\right)$; and the Pielou's evenness (J') were estimated.

In order to identify differences ( $p$-value $\leq 0.05$ ) among microcosms, the one-way ANOVA routine and the post-hoc Tukey multiple comparisons, in case of equal series, and Spjotvoll/Stoline test, in case of unequal series, were performed. For comparisons of data related to the two types of water used, the Student $t$-test was run. Populations of each species were presented in $k$-dominance plots, ranking the dominance of species in decreasing order. The percentage cumulative dominance ( $k$-dominance) was then plotted against the rank $k$ of each species (Lambshead et al., 1983). A non-metric Multidimensional Scaling ordination (nMDS) was performed on a Bray-Curtis similarity matrix based on species abundance after their square root transformation. ANOSIM analysis was used to detect possible significant differences between the nematode communities from different microcosms. Following, a one-way similarity percentage procedure (SIMPER, cut-off percentage: cut-off $70 \%$ ) was applied in order to evaluate the relative contribution of each species to the average dissimilarities among treatments.

\section{Results}

\subsection{Abiotic variables}

In the beginning of the experiment, the results obtained showed that values of $\mathrm{pH}$, conductivity, COD and BOD5 for the water treated (TW) or not (UT) were similar ( $p$-values $>0.9999$ ) (Table 1$)$. However, significant differences distinguished UT from TW when decantable and suspended materials were compared (Table 1). Similarly,

Table 1. Parameters measured in water and sediment of controls (C) and treatments (UT and TW).

\begin{tabular}{|c|c|c|c|c|}
\hline Compartments & Parameters & C & TW & UW \\
\hline \multirow[t]{6}{*}{ Water } & $\mathrm{pH}$ & - & 8.05 & 8.15 \\
\hline & Conductivity (mmoho.cm-1) & - & 57.1 & 47.9 \\
\hline & Suspended materials (mg..$\left.^{-1}\right)$ & - & $37.52 \pm 2.09(\mathrm{a})$ & $40.12 \pm 4.36(a)$ \\
\hline & $\operatorname{COD}\left(\mathrm{mgO}_{2} \cdot \mathrm{l}^{-1}\right)$ & - & $79 \pm 3(a)$ & $81 \pm 2(a)$ \\
\hline & BOD5 $\left(\mathrm{mgO}_{2} \cdot 1^{-1}\right)$ & - & $15 \pm 1(\mathrm{a})$ & $44 \pm 1$ (b) \\
\hline & Hydrocarbons (mg..$^{-1}$ ) & - & $0.18 \pm 0.04(a)$ & $0.92 \pm 0.07(b)$ \\
\hline \multirow[t]{6}{*}{ Sediment } & Coarse fraction (\%) & $92.19 \pm 3.24(\mathrm{a})$ & $93.36 \pm 4.10(a)$ & $92.79 \pm 2.52(a)$ \\
\hline & Silt/clay fraction (\%) & $7.81 \pm 3.24(\mathrm{a})$ & $6.64 \pm 4.10(a)$ & $7.21 \pm 2.52(a)$ \\
\hline & Mean grain size $(\mathrm{mm})$ & $0.29 \pm 0.02(a)$ & $0.30 \pm 0.05(a)$ & $0.30 \pm 0.04(a)$ \\
\hline & Water content (\%) & $13.01 \pm 2.24$ (a) & $14.10 \pm 3.02(a)$ & $14.89 \pm 1.48(a)$ \\
\hline & Total organic matter (\%) & $1.02 \pm 0.05(a)$ & $0.98 \pm 0.10(a)$ & $1.13 \pm 0.03(b)$ \\
\hline & Hydrocarbons (mg.g ${ }^{-1}$ ) & $0.083 \pm 0.011(\mathrm{a})$ & $0.091 \pm 0.009(\mathrm{~b})$ & $1.015 \pm 0.006 \Subset$ \\
\hline
\end{tabular}

Treated water (TW); untreated water (UW). Not considered (-). Different letters next to values indicate significant differences $(p$-values $\leq 0.05)$. 
and especially the concentration of hydrocarbons for both types of water did vary significantly ( $p$-values $<0.0001$ ).

On the sampling day, the environmental parameters were as follows: depth $=10 \mathrm{~cm}, \mathrm{pH}=8.26$, conductivity $=53.2 \mathrm{mmoho} \mathrm{cm}^{-1}$, granulometry (93.22 $\pm 3.15 \%$ coarse fraction, $6.78 \pm 3.15 \%$ silt/clay fraction, and mean grain size of $0.30 \pm 0.06 \mathrm{~mm}$ ), water content $(13.14 \pm 2.07 \%), \mathrm{TOM}=0.95 \pm 0.09 \%$, and total hydrocarbons $=0.079 \pm 0.006 \mathrm{mg}^{-1} \mathrm{~g}^{-1}$. After one month, TOM and total hydrocarbons loads in the sediment indicated significantly their highest values at TW (Table 1 ).

\subsection{Quantitative variables}

The effect of the treatments on the average abundance of the nematofauna showed distinctive results; the untreated waters were related significantly to the lowest values ( $p$-values $<0.001)$. Moreover, the post-hoc analysis of Tukey (test of Spjotvoll/Stoline) did not reveal a significant difference ( $p$-value $\leq 0.05$ ) between the mean values of the individual biomass of the control nematofauna and those exposed to the untreated water (UW) of TRIC (Figure 1).

\subsection{Taxonomic diversity}

The initial nematode assemblages (I) collected from Bizerte bay to start the experiment was composed of 16 species belonging to 16 genera and 14 families (Table 2 ). Three of them were dominant ( $>10 \%$ according to Engelmann, 1978): Microlaimus honestus (Microlaimidae, $34.33 \pm 4.04 \%$ ), Paramonohystera proteus (Xyalidae, $13 \pm 3 \%$ ) and Metoncholaimus pristiurus (Oncholaimidae, $11.33 \pm 3.06 \%$ ). At the end of the experiment, in all different communities (C, TW, UW) 16 species that belonged to 16 genera were identified (Table 2). Anticoma acuminata, M. pristiurus and Synonchiella edax were observed in all treatments. Control microcosms were characterized by the most diverse assemblage since 16 nematode species were observed. This nematofauna was dominated by $M$. honestus ( $33.36 \pm 2.64 \%$ ) and to a lesser degree $P$. proteus $(12.03 \pm 0.57 \%)$ and $M$. pristiurus $(9.25 \pm 1.52 \%)$. On the contrary, the assemblage exposed to TRIC water showed a clear reduction of the biodiversity that was more pronounced in the UW bottles (only 4 species observed) than in the TW microcosms (7 species).

In the control set up, the dominant species was $M$. honestus (33.36 $\pm 2.64 \%$ ) but absent in the other two treatments, followed by $P$. proteus (12.03 $\pm 0.57 \%)$ and M. pristiurus $(9.25 \pm 1.52 \%)$. This latter species was the most abundant in both TW and UW microcosms (69.37 $\pm 5.68 \%$ and $50 \pm 0.57 \%$, respectively).P. proteus $(12.87 \pm 1.15 \%)$ and Paracyatholaimus pugettensis $(10.88 \pm 0.57 \%)$ represented the second and the third dominant species in TW. While Thalassironus britannicus ( $30.12 \pm 0.57 \%$ ) and A. acuminata $(9.93 \pm 0.57 \%)$ represented the second and the third dominant species in UW.

The assemblage was statistically more diverse in $C$ microcosms than in the treatments (one-way ANOVA, $\mathrm{F}_{(2,6)}=236.89, \mathrm{p}<0.001$ for $\left.\mathrm{H}^{\prime}\right)$ while the evenness (J') was significantly higher in TW than in the other two microcosms (Figure 2). These results were confirmed by the graphic method of $k$-dominance (Figure 3 ). The curve related to the control microcosms was the lower one, thus showing a higher diversity compared to UW and TW microcosms.

In the nMDS plot, a clear separation of treated and untreated microcosms was highlighted (Figure 4). The ANOSIM analysis revealed significant differences in terms of nematode species composition ( $p=0.001)$. SIMPER results indicated that most contributing species to the dissimilarity between the various microcosms were M. pristiurus and M. honestus (Table 3).

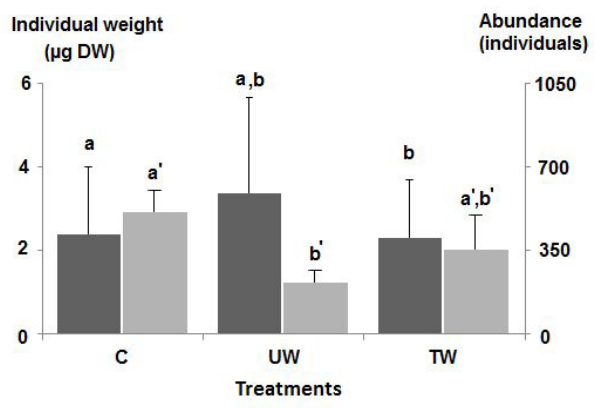

Figure 1. Changes in the abundance and individual weight of free-living marine nematodes from control microcosms (C) and those exposed to treated (TW) and untreated water (UW). Dry Weight (DW). Different letters indicate significant differences ( $p$ $\leq 0.05$ ); for details see text.

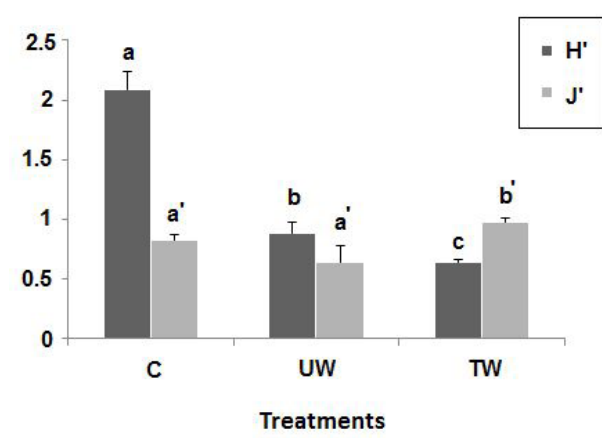

Figure 2. Shannon diversity index ( $\left.H^{\prime}\right)$ and Evenness (J') of nematode assemblages from control microcosms (C) and those exposed to treated (TW) and untreated water (UW). Different letters indicate significant differences $(p \leq 0.05)$; for details see text.

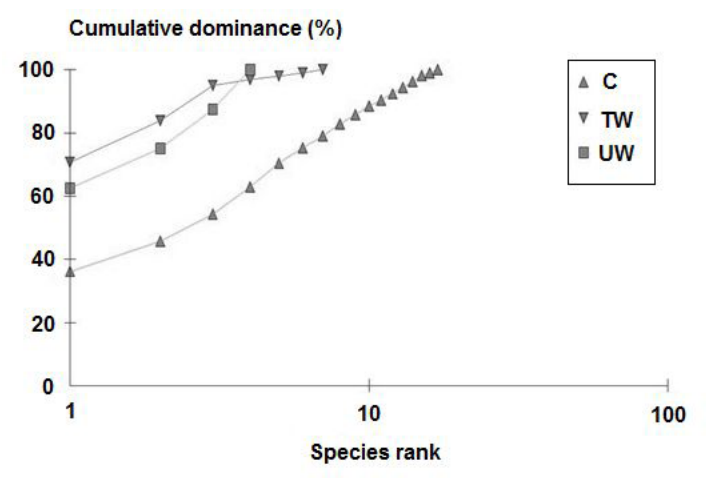

Figure 3. The $k$-dominance curves plotted from nematode assemblages from control microcosms (c) and those exposed to treated (TW) and untreated water (UW). 
Table 2. Relatives abundances of nematodes species from control microcosms (C) and those exposed to treated (TW) and untreated water (UW).

\begin{tabular}{|c|c|c|c|c|c|}
\hline \multirow{2}{*}{ Species } & \multirow{2}{*}{ FT } & \multicolumn{4}{|c|}{ Nematode assemblages } \\
\hline & & I & C & TW & UW \\
\hline Anticoma acuminata & $1 \mathrm{~A}$ & 1.67 & 1.83 & 1.96 & 9.93 \\
\hline (Eberth, 1863) Bastian 1865 & & $(0.58)$ & $(1.15)$ & $(0.57)$ & $(0.57)$ \\
\hline Microlaimus honestus & $2 \mathrm{~A}$ & 34.33 & 33.36 & - & - \\
\hline De Man 1922 & & $(4.04)$ & $(2.64)$ & & \\
\hline Cyartonema germanicum & $1 \mathrm{~A}$ & 9.33 & 8.34 & - & - \\
\hline Juario 1972 & & $(2.08)$ & -1 & & \\
\hline Enoplolaimus longicaudatus & $2 \mathrm{~B}$ & 2.67 & 2.78 & - & - \\
\hline (Southern, 1914) Filipjev 1921 & & $(2.08)$ & 0 & & \\
\hline Metoncholaimus pristiurus & $2 \mathrm{~B}$ & 11.33 & 9.25 & 69.37 & 50 \\
\hline (Zur Strassen, 1894) Filipjev 1918 & & $(3.06)$ & $(1.52)$ & $(5.68)$ & $(0.57)$ \\
\hline Odontophora villoti & 1B & 4.33 & 2.78 & 1.96 & - \\
\hline Luc and De Coninck 1959 & & $(2.08)$ & $(0.57)$ & $(0.57)$ & \\
\hline Paracyatholaimus pugettensis & $2 \mathrm{~A}$ & 2.33 & 2.78 & 10.88 & - \\
\hline Wieser and Hopper 1967 & & $(1.53)$ & $(0.57)$ & $(0.57)$ & \\
\hline Paradesmodora supplementatis & $2 \mathrm{~A}$ & 3.00 & 2.78 & - & - \\
\hline Inglis 1968 & & $(2.65)$ & $(0.57)$ & & \\
\hline Paramonohystera proteus & $1 \mathrm{~B}$ & 13.00 & 12.03 & 12.87 & - \\
\hline Wieser 1956 & & $(3.00)$ & $(0.57)$ & $(1.15)$ & \\
\hline Parasphaerolaimus paradoxus & $2 \mathrm{~B}$ & 2.67 & 2.78 & - & - \\
\hline Lorenzen 1978 & & $(2.08)$ & $(0.57)$ & & \\
\hline Phanodermopsis sp. & $2 \mathrm{~A}$ & 1.33 & 2.78 & 0.98 & - \\
\hline & & $(1.15)$ & $(1.15)$ & $(0.57)$ & \\
\hline Rhabditis sp. & 1B & 1.33 & 0.91 & - & - \\
\hline & & $(0.58)$ & $(0.57)$ & & \\
\hline Spirinia parasitifera & $2 \mathrm{~A}$ & 7.33 & 7.39 & - & - \\
\hline (Bastian, 1865) Gerlach 1963 & & $(3.06)$ & $(0.67)$ & & \\
\hline Synonchiella edax & $2 \mathrm{~B}$ & 1.33 & 4.61 & 1.96 & 9.93 \\
\hline Aissa and Vitiello, 1977 & & $(1.15)$ & $(1.15)$ & $(0.57)$ & $(0.57)$ \\
\hline Thalassironus britannicus & $2 \mathrm{~B}$ & 2.33 & 2.78 & - & 30.12 \\
\hline de Man, 1889 & & $(2.52)$ & $(0.57)$ & & $(0.57)$ \\
\hline Valvaelaimus maior & 1B & 1.67 & 2.78 & - & - \\
\hline (Gerlach 1956) & & $(2.08)$ & -1 & & \\
\hline Total number of species & & 16 & 12.33 & 4.66 & 2 \\
\hline & & 0 & $(1.52)$ & $(1.52)$ & 0 \\
\hline Total absolute abundance & & 577 & 510 & 212 & 350 \\
\hline & & -70 & -91 & -51 & -143 \\
\hline
\end{tabular}

Feeding type (FT); selective deposit feeders (1A); non-selective deposit feeders (1B); epigrowth feeders (2A); omnivores-carnivores (2B); Initial nematode assemblage taken from the field (I); Species absent (-). Values between brackets correspond to the standard deviation.

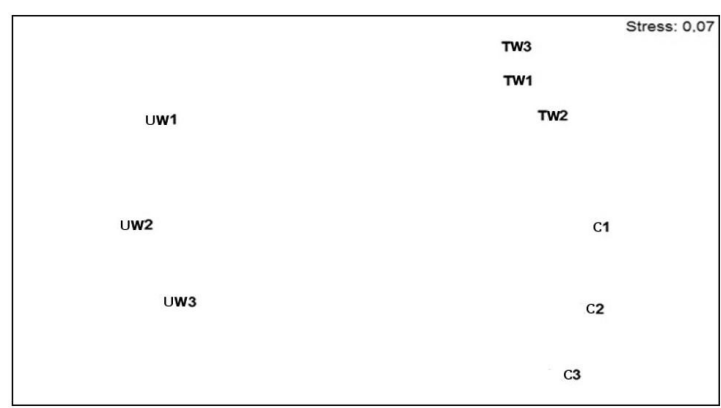

Figure 4. Non-metric MDS ordination of square-root transformed abundances of nematode species from control microcosms (C) and those exposed to treated (TW) and untreated water (UW).

\section{Discussion}

In the past no studies have been conducted in order to examine the effectiveness of treatments applied to tarred waters by petroleum industries such as the TRIC. Indicative species to define the quality status are undoubtely needed, and the nematode communities could serve as such. Indeed, these worms are the most abundant taxon in the marine benthos and characterized by their global distribution. The current experiment was conducted to see which such nematode taxa could serve as indicators to measure the efficacy of oil-treatment before rejection of TRIC.

The measurements done in sediments prior to sampling, qualified the sampling area in Bizerte bay as pristine. The 
Table 3. Species responsible for the average dissimilarity (A.D.) between control microcosms (C) and those containing treated (TW) or untreated (UW) water based on similarity percentages analysis (SIMPER). Data were square-root transformed.

\begin{tabular}{ccc}
\hline C $v$ s. TW (A.D. = 74.52\%) & C vs.UW (A.D. = 87.62\%) & TW vs. UW (A.D. = 89.29\%) \\
\hline Metoncholaimus pristiurus 38.96\% (+) & Microlaimus honestus 38.38\% elim & Metoncholaimus pristiurus 67.43\% (-) \\
Microlaimus honestus 25.19\% (elim) & Paramonohystera proteus 9.09\% elim & - \\
- & Cyartonema germanicum 9.09\% elim & - \\
\hline
\end{tabular}

Values indicate the contributions of species to the average dissimilarity. More abundant (+); less abundant (-); elimination (elim).

presence of Microlaimidae seems to indicate that the taxonomic composition was determined by the sediment texture confirmed by the results of Rzeznic-Orignac (2004), showing that homogeneous sediments generally shelter a community with low diversity. This supports the assumption that heterogeneous sediments show a diverse community structure and are more favorable to cosmopolitan species than species with stenotypic requirements.

Except the abundance, the univariate indices were not adequate in assessing the stress status in TW and UW microcosms, due to the similarities between the reference nematofaunistic average and that exposed to untreated water (UW). Nevertheless, along with multivariate analyses obtained results are of high importance to evaluate the condition of the discharged wastes. Indeed, in the frame of the current study nMDS combined with SIMPER analysis highlighted the oil-sensitive species to hydrocarbons (i.e. M. honestus) but also the oil-tolerant one (i.e. M. pristiurus) (Table 3).

Microlaimus honestus was not present in the TW and UW microcosms, but was found only in the control. This result supports the hypothesis that despite the treatments, the water (TW) may negatively impact some benthic species, such as this nematode in the experiments conducted here within. On the other hand, the results showed a lower sensitivity to hydrocarbons by other species, namely $P$. proteus and $C$. germanicum, present in both $C$ and TW microcosms. This observation was correlated with increase of average nematofauna biomass in TW, due to the proliferation of corpulent species, M. pristiurus (3-4 mm length). Our study did not allow us to decide whether the tolerance of M. pristiurus is due to a genoresistance to hydrocarbons or to an opportunism of the species benefiting from the disappearance of more sensitive species, or both. Hedfi (2008) identified M. pristiurus as bioindicator taxon since it was dominant in polluted sediment by the hydrocarbons (1.3-7.6 mg/g dry weight) of the old harbor of Bizerte before its rehabilitation. The use of $M$. pristiurus as a bio-indicator of a polluted environment is also supported by the findings presented here.

The results of this study support the hypothesis of a specific response of nematodes for the different degrees of hydrocarbon contamination, before and after the treatment of the discharged water, according to their sensitivity (Mahmoudi et al., 2005; Hedfi et al., 2013; Allouche et al., 2020). As shown here, sensitive species to hydrocarbon pollution, such as M. honestus, do not tolerate even the smallest amounts of hydrocarbon remains, since they were eliminated from both TW and UW. Another plausible explanation could be the low food availability, since the main source of its diet, benthic diatoms, are also hydrocarbon-sensitive and tend to disappear (Moens and Vincx, 1997). Moreover, the disappearance of M. honestus could also be related to its corpulence $(\approx 1 \mathrm{~mm}$ the adult), and the adhesiveness of the sediment contaminated by the hydrocarbons could hinder its mobility and restrict its activity. On the other hand, the omnivore-carnivore species like M. pristiurus was characterized by a strong potential of tolerance to hydrocarbons, that can be linked to the species euryphagous characteristics (Moens and Vincx, 1997) adapting to the availability of trophic resources. Their survivals could also be due to their larger size (3-4 mm) and their developed musculature allowing them a more ample undulatory movement in the sediment, and hence impacting little, if at all, its mobility.

Accidental discharges of tarred water in the marine environment, based on the results of this study, is more likely to be followed by a high mortality of sensitive species such $M$. honestus. The mortality of these species due to the toxicity of petroleum products or/and the viscosity of sediment seem to benefit the omnivorous-carnivorous species, such $M$. pristiurus. The comparison between the waters before (UW) and after (TW) treatment revealed a clear improvement in the quality of the water intended to be discharged into the marine environment. Indeed, this has been confirmed by a greater diversity of nematodes in TW than in UW and by the closer similarity of the TW nematofauna to that of control. The significant presence of $M$. pristiurus within TW nematofauna, could indicate a considerable hydrocarbon contamination.

\section{Conclusions}

Based on the results of the current study, there are certain nematode species that could be used as indicators of environmental status according to the degree of sensitivity to hydrocarbons. Thus, the presence of species such as $M$. honestus, P. proteus and C. germanicum can be considered as bioindicator of a good environmental status with respect to hydrocarbon contamination. In the contrary, M. pristiurus can be considered as bioindicator of a bad environmental status, with respect to hydrocarbon contamination, as it was proven as hydrocarbon-tolerant. The negative effects of TRIC waste waters appeared significantly reduced after their treatments in decantation basins before rejection in Bizerte bay. Yet, further studies similar to this presented here need to be conducted in order to establish a certified classification of species as positive or negative indicators of petroleum pollution. 


\section{Acknowledgements}

This work was supported by the Tunisian Ministry of the High Education and Scientific Research. The authors are grateful to the Deanship of Scientific Research for funding this article by Taif University Research Supporting Project number (TURSP - 2020/141), Taif University, Taif, Saudi Arabia.

\section{References}

ALLOUCHE, M., HAMDI, I., NASRI, A., HARRATH, A.H., MANSOUR, L., BEYREM, H. and BOUFAHJA, F., 2020. Laboratory bioassay exploring the effects of anti-aging skincare products on freeliving marine nematodes: case study of collagen. Environmental Science and Pollution Research International, vol. 27, no. 10, pp. 11403-11412. http://dx.doi.org/10.1007/s11356-020-07655-1. PMid:31965497.

AMINOT, A. and KÉROUEL, R., 2004. Hydrologie des écosystèmes marins: paramètres et analyses. France: Éditions Quae, 336 p.

AUSTEN, M.C., MCEVOY, A.J. and WARWICK, R.M., 1994. The specificity of meiobenthic community responses to different pollutants: results from microcosm experiments. Marine Pollution Bulletin, vol. 28, no. 9, pp. 557-563. http://dx.doi. org/10.1016/0025-326X(94)90075-2.

BASTIAN, H.C., 1865. Monograph of the anguillulidae, or free nematoids, marine, land, and freshwater; with descriptions of 100 new species. London: The Transactions of the Linnean Society of London, vol. XXV, pt. II, pp. 73-184.

BEYREM, H. and AISSA, P., 2000. Les nématodes libres, organismes sentinelles de l'évolution des concentrations d'hydrocarbures dans la baie de Bizerte (Tunisie). Cahiers de Biologie Marine, vol. 41, pp. 329-342.

BEYREM, H., MAHMOUDI, E., ESSID, N., HEDFI, A., BOUFAHJA, F. and AISSA, P., 2007. Individual and combined effects of cadmium and diesel on a nematode community in a laboratory microcosm experiment. Ecotoxicology and Environmental Safety, vol. 68, no. 3, pp. 412-418. http://dx.doi.org/10.1016/j.ecoenv.2006.12.007. PMid: 17303240.

BEZERRA, T.N., DECRAEMER, W., EISENDLE-FLOCKNER, U., HODDA, M., HOLOVACHOV, O., LEDUC, D., MILJUTIN, D., MOKIEVSKY, V., PENA SANTIAGO, R., SHARMA, J., SMOL, N., TCHESUNOV, A., ENEKEY, V., ZHAO, Z. and VANREUSEL, A. 2020. Nemys: world database of nematodes [online]. Ghent University. Available from: http://nemys.ugent.be/

BOUFAHJA, F., HEDFI, A., AMORRI, J., AISSA, P., MAHMOUDI, E. and BEYREM, H., 2011. Experimental validation of the 'Relative Volume of the Pharyngeal Lumen (RVPL)' of free-living nematodes as a biomonitoring index using sediment-associated metals and/or Diesel Fuel in microcosms. Journal of Experimental Marine Biology and Ecology, vol. 399, no. 2, pp. 142-150. http:// dx.doi.org/10.1016/j.jembe.2011.01.017.

BUCHANAN, J.B., 1971. Measurement of the physical and chemical environment: sediments. In: N.A. HOLME and A.D. MCINTYRE, eds. Methods for the study of marine benthos. Oxford: Blackwell Scientific Publications, 334 pp. International Biological Programme Handbook, no. 16.

CLARKE, K.R. and GORLEY, R.N., 2001. PRIMER v5: User manual/ tutorial. Plymouth, UK: PRIMER-E, $91 \mathrm{p}$.

CLARKE, K.R., 1993. Non-parametric multivariate analyses of changes in community structure. Australian Journal of Ecology, vol. 18, no. 1, pp. 117-143. http://dx.doi.org/10.1111/j.1442-9993.1993. tb00438.x.
COULL, B.C. and CHANDLER, G.T., 1992. Pollution and meiofauna: field, laboratory and mesocosm studies. Oceanography and Marine Biology, vol. 30, pp. 191-271.

DANOVARO, R., FABIANO, M. and VINCX, M., 1995. Meiofauna response to the Agip Abruzzo oil spill in subtidal sediments of the Ligurian Sea. Mar Pollut Bull 39: 133-145Engelmann H.D. 1978. Zur Dominanzklassifizierung von Bodenarthropoden. Pedobiologia, vol. 18, pp. 378-380.

ENGELMANN, H.D., 1978. Zur Dominanzklassifizierung von Bodenarthropoden. Pedobiologia, vol. 18, pp. 378-380.

ESSID, N., GHARBI, R., HARRATH, A.H., MANSOUR, L., MAHMOUDI, E., BEYREM, H., ANSARI, K.G.M.T. and BOUFAHJA, F., 2020. Toxicity of a chromium-enriched superfood, Spirulina platensis, assessed by taxonomic and morpho-functional diversity of marine meiofauna. Environmental Pollution, vol. 262, pp. 114350. http://dx.doi.org/10.1016/j.envpol.2020.114350. PMid:32197121.

FABIANO, M. and DANOVARO, R., 1994. Composition of organic matter in sediment facing a river estuary (Tyrrhenian Sea): relationships with bacteria and microphytobenthic biomass. Hydrobiologia, vol. 277, no. 2, pp. 71-84. http://dx.doi. org/10.1007/BF00016755.

GUO, Y., SOMERFIELD, P.J., WARWICK, R.M. and ZHANG, Z., 2001. Large-scale patterns in the community structure and biodiversity of free living nematodes in the Bohai Sea, China. Journal of the Marine Biological Association of the United Kingdom, vol. 81, no. 5, pp. 755-763. http://dx.doi.org/10.1017/S0025315401004568.

HEDFI, A., 2008. Les nématodes libres, outils communautaires de biosurveillance du milieu marin: études in situ et en microcosmes. Zarzouna, Tunísia: Faculty of Sciences of Bizerte, 247 p. Phd thesis in Biological Sciences.

HEDFI, A., BENALI, M., HASSAN, M.M., ALBOGAMI, B., AL-ZAHRANI, S.S., MAHMOUDI, E., KARACHLE, P.K., ROHAL-LUPHER, M. and BOUFAHJA, F., 2021. Nematode traits after separate and simultaneous exposure to Polycyclic Aromatic Hydrocarbons (anthracene, pyrene and benzo[a]pyrene) in closed and open microcosms. Environmental Pollution, vol. 276, pp. 116759. http://doi.org/10.1016/j.envpol.2021.116759.

HEDFI, A., BENALI, M., NOUREL-DEEN, A., ALBOGAMI, B., HASSAN, M., SAIF, T. and BOUFAHJA, F., 2018. Distribution and Abundance of Benthic Meiofauna in the Eastern Red Sea Coasts (Jeddah, Saudi Arabia). Annual Research \& Review in Biology, vol. 26, no. 2, pp. 1-12. http://dx.doi.org/10.9734/ARRB/2018/41312.

HEDFI, A., BOUFAHJA, F., BEN ALI, M., AISSA, P., MAHMOUDI, E. and BEYREM, H., 2013. Do trace metals (chromium, copper, and nickel) influence toxicity of diesel fuel for free-living marine nematodes? Environmental Science and Pollution Research International, vol. 20, no. 6, pp. 3760-3770. http://dx.doi. org/10.1007/s11356-012-1305-2. PMid:23179214.

HEDFI, A., MAHMOUDI, E., BEYREM, H., BOUFAHJA, F., NACEUR, E. and AISSA, P., 2008. Réponse d'une communauté de nématodes libres marins à une contamination par le cuivre: étude microcosmique. Bulletin de la Société Zoologique de France, vol. 133, no. 1-3, pp. 93-102.

HEDFI, A., MAHMOUDI, E., BOUFAHJA, F., BEYREM, H. and AISSA, P., 2007. Effects of increasing levels of nickel contamination on structure of offshore nematode communities in experimental microcosms. Bulletin of Environmental Contamination and Toxicology, vol. 79, no. 3, pp. 345-349. http://dx.doi.org/10.1007/ s00128-007-9261-0. PMid:17712504.

KENNISH, M.J., 1992. Polynuclear aromatic hydrocarbons. In: M.J. KENNISH. Ecology of estuaries: anthropogenic effects. Boca Raton: CRC Press, pp. 133-181 
KOTTA, J. and BOUCHER, G., 2001. Interregional variation of free living nematode assemblages in tropical coral sands. Cahiers de Biologie Marine, vol. 42, pp. 315-326.

LAMBSHEAD, P.J.D., PLATT, H.M. and SHAW, K.M., 1983. The detection of differences among assemblages of marine benthic species based on an assessment of dominance and diversity. Journal of Natural History, vol. 17, no. 6, pp. 859-874. http://dx.doi. org/10.1080/00222938300770671.

MAHMOUDI, E., BEYREM, H. and AISSA, P., 2003. Les peuplements de nématodes libres, indicateurs du degré d'anthropisation des milieux lagunaires: Cas de la lagune de Bou Ghrara (Tunisie). Vie et Milieu, vol. 53, pp. 47-59.

MAHMOUDI, E., ESSID, N., BEYREM, H., HEDFI, A., BOUFAHJA, F., VITIELLO, P. and AISSA, P., 2005. Effects of hydrocarbon contamination on a free living marine nematode community: results from microcosm experiments. Marine Pollution Bulletin, vol. 50, no. 11, pp. 1197-1204. http://dx.doi.org/10.1016/j. marpolbul.2005.04.018. PMid:15896812.

MOENS, T. and VINCX, M., 1997. Observations on the feeding ecology of estuarine nematodes. Journal of the Marine Biological Association of the United Kingdom, vol. 77, no. 1, pp. 211-227. http://dx.doi.org/10.1017/S0025315400033889.

NASRI, A., ALLOUCHE, M., HANNACHI, A., HARRATH, A.H., ALDAHMASH, W., ALWASEL, S., MAHMOUDI, E., BEYREM, H. and BOUFAHJA, F., 2020. Restructuring of a meiobenthic assemblage after sediment contamination with an antibacterial compound: case study of ciprofloxacin. Ecotoxicology and Environmental Safety, vol. 205, pp. 111084. http://dx.doi.org/10.1016/j. ecoenv.2020.111084. PMid:32810644.

PLATT, H.M. and WARWICK, R.M., 1983. Free-living marine nematodes. Part I. British Enoploids. London: Cambridge University, 307 p.

PLATT, H.M. and WARWICK, R.M., 1988. Free-living marine nematodes. Part II. British Chromadorids. England: Field Studies Council (FSC), Synopsis of the British fauna, vol. 38.

RODIER, J., 1996. L'analyse de l'eau, eaux naturelle, eaux résiduaire, eaux de mer. Paris: DUNOD, 1432 p. Huitième etsixième édition.

ROHAL, M., BARRERA, N., VAN EENENNAAM, J.S., FOEKEMA, E.M., MONTAGNA, P.A., MURK, A.J., PRYOR, M. and ROMERO, I.C., 2020. The effects of experimental oil-contaminated marine snow on meiofauna in a microcosm. Marine Pollution Bulletin, vol. 150 , pp. 110656. http://dx.doi.org/10.1016/j.marpolbul.2019.110656. PMid:31678679.
RZEZNIC-ORIGNAC, J., 2004. Contribution de la méiofaune aux transferts des métaux dans le réseau trophique de la Baie de Gdansk (Baltique) et de la baie de Marennes Oléron (Atlantique). French: University of la Rochelle, 266 p. Phd thesis in Biological Oceanography and Marine Environment.

SALIOT, A., 1981. Natural hydrocarbons in sea water. In E. K. DUURSMA and R. DAWSON, eds, Marine organic chemistry. Amsterdam: Elsevier, pp. 327-374.

SEINHORST, J.W., 1959. A rapid method for the transfer of nematodes from fixative to anhydrous glycerine. Nematologica, vol. 4, no. 1, pp. 67-69. http://dx.doi.org/10.1163/187529259X00381.

VANAVERBEKE, J., ARBIZU, P.M., DAHMS, H.-U. and SCHMINKE, H.K., 1997. The metazoan meiobenthos along a depth gradient in the Arctic Laptev sea with special attentions to nematode communities. Polar Biology, vol. 18, pp. 391-401.

WAKKAF, T., ALLOUCHE, M., HARRATH, A.H., MANSOUR, L., ALWASEL, S., MOHAMED THAMEEMUL ANSARI, K.G., BEYREM, H., SELLAMI, B. and BOUFAHJA, F., 2020. The individual and combined effects of cadmium, Polyvinyl chloride (PVC) microplastics and their polyalkylamines modified forms on meiobenthic features in a microcosm. Environmental Pollution, vol. 266, no. Pt 1, pp. 115263. http://dx.doi.org/10.1016/j.envpol.2020.115263. PMid:32768926.

WARWICK, R.M., PLATT, H.M. and SOMERFIELD, P.J., 1998. Free-living marine nematodes. Part III. British monohysterids. Shrewsbury: Field Studies Council. Synopsis of British fauna, no. 53.

WIESER, W., 1960. Benthic studies in Buzzards Bay. II. The meiofauna. Limnology and Oceanography, vol. 5, no. 2, pp. 121-137. http:// dx.doi.org/10.4319/lo.1960.5.2.0121.

ZRAFI-NOUIRA, I., KHEDIR-GHENIM, Z., BAHRI, R., CHERAEIF, I., ROUABHIA, M. and SAIDANE-MOSBAHI, D., 2009. Hydrocarbons in seawater and water extract of Jarzouna-Bizerte Coastal of Tunisia (Mediterranean Sea): Petroleum origin investigation around refinery rejection place. Water, Air, and Soil Pollution, vol. 202, no. 1-4, pp. 19-31. http://dx.doi.org/10.1007/s11270008-9955-X.

ZRAFI-NOUIRA, I., SAFI, N.M.D., BAHRI, R., MZOUGHI, N., AISSI, A., ABDENNEBI, H.B. and SAIDANE-MOSBAHI, D., 2010. Distribution and sources of polycyclic aromatic hydrocarbons around a petroleum refinery rejection area in Jarzouna-Bizerte (Coastal Tunisia). Soil \& Sediment Contamination, vol. 19, no. 3, pp. 292306. http://dx.doi.org/10.1080/15320381003695223. 